\title{
Výzva pro pedagogický výzkum - odborné školství a odborné vzdělávání
}

\author{
Jan Prưcha
}

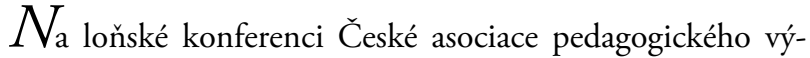
zkumu (Zlín, 2018) jsem ve svém vystoupení kriticky poukázal na jednu oblast současné edukační reality, která je českým pedagogickým výzkumem opomíjena - je to široká oblast odborného školství a odborného vzdělávání. Existuje zde velký paradox: $\mathrm{Na}$ jedné straně se česká společnost a zejména ekonomika pozitivně rozvíjí právě $\mathrm{v}$ důsledku toho (mimo jiných okolností), že máme vyspělé odborné vzdělávání, jež některými svými parametry patř́ $\mathrm{k}$ nejúspěšnějším ve světě - a na druhé straně je nepříznivou skutečností, že česká pedagogická teorie a především pedagogický výzkum se o tuto důležitou oblast skoro vủbec nezajímají. O tom se lze snadno přesvědčit: Není u nás vypracována fundamentální monografie o důležitých tématech odborného školství, nemáme specializovaný vědecký časopis o odborném vzdělávání, v českých pedagogických časopisech se nesetkáváme posledních 10-20 let téměr se žádnými př́spěvky o odborném vzdělávání. Veškerý zájem pedagogických výzkumníků se soustředuje na problematiku všeobecného školství a všeobecného vzdělávání.

Jsou, pravda, některé pozitivní výjimky. Zejména pracovníci z bývalého (bohužel zrušeného) Národního ústavu odborného vzdělávání (dřive Výzkumného ústavu odborného školství), kteří jsou od roku 2012 začleněni do Národního ústavu pro vzdělávání, se zabývají podrobnými kvantitativními analýzami různých stránek odborného školství (viz příspěvky J. Vojtěcha a dalších $\mathrm{v}$ tomto čísle). D. Vaněček s několika spolupracovníky vypracovali rozsáhlou publikaci o didaktice technických odborných
\end{abstract}


předmětů (viz o ní recenzi v tomto čísle). Ojediněle se objevují dílčí výzkumy vztahující se např. $\mathrm{k}$ volbě studia na středních odborných školách u mladých lidí (P. Hlad'o aj.). Jsou to však skutečné výjimky, systematický výzkum odborného školství a vzdělávání u nás neexistuje.

Přitom se ozývají často apely $\mathrm{z}$ řad představitelů průmyslu, podnikatelů, ekonomických odborníků, politiků i širší veřejnosti, které kriticky poukazují na různé nedostatky: nedostačující počty mladých lidí na technických oborech studia, malý zájem o př́pravu kvalifikovaných řemeslníků, absence bývalé polytechnické přípravy již na základních školách a další. Jenže tyto kritické hlasy se př́liš nesetkávají s odezvou mezi pedagogickými výzkumníky. Přetrvává u nás jakási bariéra - jako by pedagogika byla čistě humanitní věda, které př́íslušejí témata všeobecného vzdělávání, kdežto problémy odborného a zvláště technického vzdělávání jí nepř̌islušejí. Jenže komu tedy?

Přitom oblast odborného vzdělávání má u nás skvělé historické tradice, jak pokud jde o zakládání středních odborných škol (průmyslovek) a technických a zemědělských vysokých škol, tak z hlediska využívání poznatků o odborném vzdělávání ze zahraničí. Stojí za připomenutí, že již v polovině 19. století Dr. Tech. Karel Kořistka, profesor pražské polytechnické školy (předchůdkyně ČVUT) podnikal studijní cesty do různých evropských zemí a publikoval o tom spis Die höhere polytechnische Unterricht in Deutschland, in der Schweiz, in Frankreich, in Belgien und England
(1863). Dnes u nás nemáme systematický komparativní pohled na odborné školství v zahraničí. Různé inovace v odborném školství z cizích zemí k nám nepronikají prostřednictvím zainteresovaných pedagogů, o zahraničních trendech týkajících se např. učňovského školství se u nás skoro nic neví.

Co tedy potřebujeme? Když porovnávám situaci ve výzkumu odborného školství a vzdělávání v zahraničí a $\mathrm{u}$ nás, vyplývají z toho určité návrhy pro realizaci soustavného a komplexního zkoumání této oblasti edukační reality.

Především musíme v ČR vybudovat vědecký obor zabývající se systematicky odborným vzděláváním. Tento výzkum musí být komplexní $\mathrm{v}$ tom, že bude pokrývat všechny složky a aktéry odborného vzdělávání. Tedy subjekty působící v odborném vzdělávání; edukační procesy, jimiž se odborné vzdělávání realizuje; výstupy, které z této realizace vznikají; efekty, které jsou těmito výsledky vytvářeny $\mathrm{v}$ ekonomice a jiných sférách společnosti.

Nezbytnou součástí teorie a výzkumu odborného vzdělávání musí být fungující infrastruktura. K tomu je třeba (1) vytvořit vědecké centrum pro výzkum odborného vzdělávání, (2) začít vydávat vědecký časopis pro odborné vzdělávání, (3) organizovat celostátní konference a sít pracovníků zabývajících se odborným vzděláváním. Zároveň je nutno spolupracovat se sférou praxe, se zaměstnavateli a reprezentacemi různých sektorů národního hospodářství. Tyto návrhy jsem podrobněji vysvětlil v monografii Odborné skolství a odborné vzdèláváni (2019). 
Toto monotematické číslo je vytvořeno právě $\mathrm{k}$ tomu účelu, aby podnítilo zájem českých pedagogů o problematiku odborného školství a vzdělávání. Bylo poměrně obtížné objevit prríspěvky, které se zabývají empirickým výzkumem odborného vzdělávání nebo alespoň nepřímo s ním souvisejí. Podařilo se shromáždit deset př́spěvků, jež jsou tematicky různorodé, ale podle mého názoru užitečné. První dvě studie pojednávají o studentech ve vyšším sekundárním vzdělávání, a to jednak z hlediska vstupů do středoškolských maturitních oborů (J. Straková, J. Simonová, D. Greger), jednak v aspektu meziškolní mobility žáků středních odborných škol (D. Dvořák, J. Vyhnálek). Bude zajímavé tuto druhou práci (aplikující kvantitativní metodologii) srovnávat $s$ další studií, která se rovněž zabývá meziškolní mobilitou ve středním odborném vzdělávání, ale z pohledu samotných žáků a $s$ aplikací kvalitativní metodologie (P. Hlad'o, K. Šlapalová).

Další studie se zaměřují na důležitou problematiku začleňování učiva o technice do kurikula základních škol (J. Dostál) a na neméně významnou problematiku dalšího vzdělávání učitelů odborných před- mětů (P. Adamec). Je zastoupena i problematika využívání kariérového poradenství žáky středních odborných škol (L. Hloušková). Další př́spěvek informuje o zahraničních systémech odborného vzdělávání ve třech vybraných zemích (J. Průcha).

Výše zmíněné pracoviště zabývající se odborným školstvím v NÚV je zastoupeno třemi analytickými zprávami. Je objasněn vývoj vzdělanostní struktury středního a vyššího vzdělávání včetně odborného vzdělávání (J. Vojtěch, M. Úlovec). Další př́ispěvek popisuje populaci absolventů středních odborných škol a jejich přechod do trhu práce (J. Trhlíková) a je vysvětleno, jaké revize kurikulárních dokumentů pro střední odborné školství se provádějí a plánují (O. Kofroňová).

Rukopisné texty všech prríspěvků procházely anonymním posouzením vždy dvou nezávislých odborníků. Jako bylo nesnadné shromáždit tematicky relevantní príspěvky pro toto monotematické číslo, tak bylo rovněž obtížné najít kompetentní posuzovatele rukopisů. Jako garant tohoto speciálního čísla bych chtěl vyslovit poděkování zúčastněným autorům i všem recenzentům, kteří byli ochotni rukopisy posoudit. 